\title{
PENGARUH PEMBIAYAAN UED-SP TERHADAP EFEKTIVITAS USAHA MASYARAKAT DESA PADA BIDANG PERTANIAN KECAMATAN BANTAN
}

\author{
Irawan Fakhrudin Mahalizikri, Nelly Agus Tantiana \\ Sekolah Tinggi Ilmu Ekonomi (STIE) Syariah Bengkalis \\ irawanfma@gmail.com,nelly.agus.t@ymail.com
}

https://doi.org/10.46367/jas.v4i1.198

Received: Jan 31, 2020 Revised: Apr 02, 2020 Accepted: Mei 18, 2020 Published: Jun 25, 2020

\begin{abstract}
This research aims to determine how much influence the funding of UED-SP on the efforts of rural communities in agriculture in the District of Bantan. The type of data from this research is quantitative using primary and secondary data. The population in this research were all customers who borrowed UED-SP in agriculture in the District of Bantan, amounting to 261 people, while the sample taken was as many as 158 people. The data analysis technique used is simple linear regression. The results of this research are that there is a significant influence between the funding of UED-SP on the effectiveness of rural communities in the agriculture sector of Bantan District, with a percentage value of $54.4 \%$.
\end{abstract}

Keyword: UED-SP Financing, Effectiveness, Agriculture.

\begin{abstract}
ABSTRAK
Penelitian ini bertujuan untuk mengetahui seberapa besar pengaruh pembiayaan UED-SP terhadap usaha masyarakat desa pada bidang pertanian Kecamatan Bantan. Jenis data dari penelitian ini adalah kuantitatif dengan menggunakan data primer dan sekunder. Populasi dalam penelitian ini adalah seluruh nasabah yang meminjam UED-SP di bidang pertanian yang ada di Kecamatan Bantan yaitu sejumlah 261 orang, sedangkan sample yang diambil adalah sebanyak 158 orang. Teknik analisis data yang digunakan yaitu regresi linier sederhana. Adapun hasil dari penelitian ini adalah terdapat pengaruh yang signifikan antara pembiayaan UED-SP terhadap efektivitas usaha masyarakat desa pada bidang pertanian Kecamatan Bantan yaitu dengan nilai persentase sebesar 54,4\%.
\end{abstract}

Kata Kunci: Pembiayaan UED-SP, Efektifitas, Pertanian.

\section{PENDAHULUAN}

Di era globalisasi ini ada banyak lembaga keuangan yang dapat memberi bantuan dana, seperti penggadaian, pasar modal, bank dan sebagainya. Meskipun demikian, dalam kenyataannya tidak semua pelaku usaha dapat dengan mudah mengakses sumber dana dari setiap jenis sumber dana tersebut. Kesulitan memperoleh dana tersebut disebabkan oleh masing-masing lembaga keuangan ini 
menerapkan ketentuan yang tidak mudah dapat dipenuhi oleh pihak yang membutuhkan dana.

Keberadaan lembaga keuangan yang menawarkan berbagai bentuk fasilitas pembiayaan alternatif bagi dunia usaha dalam sistem perekonomian modern sangat di butuhkan, Lembaga pembiayaan di perlukan guna mendukung dan memperkuat suatu sistem keuangan nasional yang terdiversifikasi sehingga dapat memberikan alternatif yang lebih banyak bagi pengembangan sektor usaha (Soemitra 2009, 333).

Di Indonesia lembaga pembiayaan ini di atur dalam Keputusan Presiden No. 61 Tahun 1988. Lembaga pembiayaan adalah badan usaha yang melakukan kegiatan usaha pembiayaaan dalam bentuk penyediaan dana ataupun barang modal. Menurut ketentuan Pasal 1 Ayat (2) Keputusan Presiden tersebut di atas, lembaga pembiayaan adalah badan usaha yang melakukan kegiatan pembiayaan dalam bentuk penyedian dana atau barang modal dengan tidak menarik dana secara langsung dari masyarakat (Hermansyah 2006, 12).

Mengingat banyaknya kendala untuk memperoleh dana dari bank ini, lembaga pembiayaan merupakan salah satu sumber dana alternatif yang penting dan potensial yang patut dipertimbangkan. Pilihan masyarakat terhadap lembaga pembiayaan selain disebabkan alasan di atas juga disebabkan adanya kebutuhan akan pelayanan yang cepat, prosedur yang tidak rumit dan persyaratan yang mudah sehingga semua masyarakat yang ingin meminjam dana untuk modal usaha dapat terpenuhi secara menyeluruh.

Oleh sebab itu pemerintah memfasilitasi masyarakat desa untuk membentuk suatu Lembaga Pembiayaan Desa yang disebut dengan Usaha Ekonomi Desa Simpan Pinjam (UED-SP) yang kegiatan usahanya berkonsentrasi pada penyaluran dana usaha kepada masyarakat desa dan dikelola sendiri oleh masyarakat desa tersebut.

Usaha Ekonomi Desa Simpan-Pinjam (UED-SP) merupakan lembaga yang bergerak di bidang simpan pinjam dan merupakan milik masyarakat desa kelurahan yang diusahakan serta dikelola oleh masyarakat desa/kelurahan (Aryani 2018, 16). Dengan adanya Usaha Ekonomi Desa Simpan-Pinjam (UED-SP) tersebut masyarakat bisa membuka dan mengembangkan usaha.

Usaha Ekonomi Desa Simpan Pinjam (UED-SP) diatur oleh Peraturan Menteri Dalam Negeri (Permendagri) Nomor 6 Tahun 1998 Tentang Usaha Ekonomi Desa Simpan Pinjam (UED-SP). Pasal 1 huruf d menyebutkan bahwa: "Usaha Ekonomi Desa Simpan Pinjam (UED-SP) adalah suatu lembaga yang bergerak di bidang simpan pinjam dan merupakan milik masyarakat desa/ kelurahan yang diusahakan serta dikelola oleh masyarakat desa/kelurahan" (Kemendagri 1998).

Banyak sekali usaha-usaha yang sudah mendapatkan modal dari dana Usaha Ekonomi Desa Simpan Pinjam (UED-SP) salah satunya yaitu usaha yang bergerak di bidang pertanian. Berdasarkan informasi dari Dinas Pemberdayaan Masyarakat Dan Desa (DPMD) Kabupaten Bengkalis, penyaluran dana Usaha Ekonomi Desa Simpan Pinjam (Ued-Sp) yang meminjam untuk usaha pertanian. Pembiayaan Dana Ued-Sp itu di salurkan untuk keperluan yang produktif atau di prioritaskan pada masyarakat yang memiliki usaha kecil menengah yang perlu diberikan tambahan modal untuk meningkatkan usahanya. Sebagian ada yang berhasil mengelola dengan baik, dan ada juga sebagian dari pengelolaan Ued-Sp 
yang kesulitan dalam mengelola lembaga simpan pinjam tersebut lantaran banyaknya masyarakat yang menggunakan dana tersebut kearah konsumtif, sehingga program pemerintah yang memang memfokuskan pendanaan tersebut untuk usaha-usaha produktif tidak tepat sasaram di dalam pelaksanaan.

Dengan demikian penulis tertarik melakukan penelitian dengan tujuan Untuk mengetahui efektivitas usaha masyarakat yang meminjam Ued-Sp pada bidang pertanian Kecamatan Bantan. Untuk mengetahui pengaruh pembiayaan Ued-Sp terhadap efektivitas usaha masyarakat desa yang meminjam Ued-Sp pada bidang pertanian di Kecamatan Bantan.

\section{TELAAH LITERATUR}

\section{Konsep Pembiayaan}

Ada banyak sekali definisi tentang pembiayaan atau financing. Definisi yang paling umum adalah pendanaan atau penyaluran dana. Sementara World Bank pembiayaan atau financing mendefinisikan sebagai suatu pendanaaan yang di berikan oleh suatu pihak kepada pihak lain untuk mendukung investasi yang telah di rencanakan, baik di lakukan sendiri maupun lembaga. Dengan kata lain, pembiayaan adalah pendanaan yang di keluarkan untuk mendukung investasi yang telah di rencanakan (Alma dan Donni 2014, 271).

Menurut Dahlan Siamat dalam bukunya Manajemen Lembaga Keuangan menjelaskan bahwa penyaluran dana disebut dengan pembiayaan. "dalam penyaluran dana bank syariah harus berpedoman pada prinsip kehati-hatian. Sehubungan dengan hal itu bank di wajibkan untuk meneliti secara saksama calon nasabah penerima dana berdasarkan azas pembiayaan yang sehat (Siamat 2001, 192).

Pembiayaan merupakan salah satu tugas pokok bank yaitu pemberian fasilitas penyediaan dana untuk memenuhi kebutuhan pihak-pihak yang merupakan defisit unit. Menurut sifat penggunaannnya, pembiayaan dapat dibagi menjadi dua hal, yaitu: (1) Pembiayaan produktif, pembiayaan yang di tujukan untuk memenuhi kebutuhan produksi dalam arti luas yaitu untuk peningkatan usaha baik usaha produksi, perdagangan, maupun investasi. (2) Pembiayaan konsumtif, pembiayaan yang telah di gunakan untuk memenuhi kebutuhan konsumsi, yang akan habis digunakan untuk memenuhi kebutuhan (Antonio 2001, 160).

Secara umum tujuan pembiayaan dibedakan menjadi dua kelompok yaitu: pembiayaan tingkat makro dan tujuan pembiayaan untuk tingkat mikro. Secara makro bertujuan untuk: (1) Peningkatan ekonomi umat, artinya: masyarakat yang tidak dapat di akses secara ekonomi, dengan adanya pembiayaan mereka dapat melakukan akses ekonomi. Dengan demikian dapat meningkatkan taraf ekonomi. (2) Tersedianya dana bagi peningkatan usaha, artinya: untuk pengembangan usaha untuk membutuhkan dana tambahan. Dana tambahan ini dapat diperoleh melakukan aktivitas pembiayaan. Pihak yang surplus dana menyalurkan kepada pihak minus dana selagi dapat tergulir. (3) Meningkatkan prokdutifitas, artinya: adanya pembiayaan memberikan peluang bagi masyarakat, usaha mampu meningkatkan daya produksinya. Sebab upaya produksi tidak akan dapat jalan tanpa adanya dana. (4) Membuka lapangan kerja baru, artinya: dengan adanya di bukanya sektor usaha melalui penambahan dana pembiayaan, maka sektor usaha 
tersebut akan menyerap tenaga kerja. Hal ini berarti menambah dan membuka lapangan kerja baru. (5) Terjadinya distribusi pendapatan, artinya: masyarakat usaha produktif mampu melakukan aktifitas kerja, mereka akan memperoleh pendapatan dari hasil usahanya. Penghasilan merupakan bagian dari pendapatan masyarakat. Jika ini terjadi maka akan terdistribusinya pendapatan (Saputra 2014, 15-16).

\section{Konsep Mudharabah}

Mudharabah adalah akad yang telah di kenal oleh umat muslim sejak zaman nabi, bahkan telah di praktikkan oleh bangsa arab sebelum turunnya Islam. Ketika Nabi Muhammad Saw berprofesi sebagai pedagang, iya melakukan akad mudharabah dengan Khadijah. Dengan demikian, tinjauan dari segi hukum islam maka praktik mudharabah ini di perbolehkan baik menurut Al-Qur'an, Sunnah maupun Ijma'. Dalam praktik mudharabah antara Khadijah dengan nabi, saat itu Khadijah mempercayakan barang dagangannya untuk di jual oleh nabi Muhammad Saw keluar negeri. Dalam khasus ini, Khadijah berperan sebagai pemilik modal (shahib al-maal), sedangkan nabi berperan sebagai pelaksana usaha (mudhorib). Bentuk kontrak antara kedua belah pihak berperan sebagai pemilik modal mempercayakan sejumlah modalnya untuk dikelola oleh pihak kedua, yakni si pelaksana usaha, dengan tujuan untuk mendapatkan keuntungan (Karim 2006, 204).

Mudharabah berasal dari kata dharb, berarti memukul atau berjalan. Pengertian memukul atau berjalan ini lebih tepatnya adalah proses seseoang memukulkan kakinya daam menjalankan usahanya (Muhammad 2008, 241).

Adapun secara etimologis mudharabah mempunyai arti berjalan diatas bumi yang biasa dinamakan dengan berpergian. Secara termonologis mudharabah adalah kontrak (perjanjian) antara pemilik modal ( $\mathrm{rab}$ al-mal) dan pengguna dana (mudhorib) untuk digunakan untuk aktivitas yang produktif dimana keuntungan dibagi dua antara pemodal dan pengelola modal. Kerugian jika ada di tanggung oleh pemilik modal, jika kerugian terjadi dalam keadaan normal, pemodal ( $r a b$ almal) tidak boleh intervensi kepada pengguna dana (mudhorib) dalam menjalankan usahanya (Mardani 2012, 195).

Berdasarkan PSAK No. 105 mudharabah adalah akad kerjasama usaha antara dua pihak dimana pihak pertama (pemilik dana) menyediakan seluruh dana, sedangkan pihak kedua (pengelola dana) bertindak sebagai selaku pengelola dan keuntungan dibagi antara mereka sesuai kesepakatan sedangkan kerugian finansial hanya di tanggung oleh pemilik dana.

Mudharabah adalah penanaman dana kepada pengelola dana untuk melakukan kegiatan usaha tertentu, dengan pembagian menggunakan metode bagi untung (profit sharing) atau juga metode pendapatan (net renue sharing) antara kedua belah pihak berdasarkan nisbah yang disepakati (Usanti 2013, 18).

Dalam akad mudharabah, kepercayaan merupakan sangat penting sehingga pemilik dana tidak boleh ikut campur di dalam manajemen perusahaan atau proyek yang dibiayai dengan dana dari pemilik dana tersebut, kecuali sebatas memberikan saran-saran dan melakukan pengawasan terhadap pihak pengelola dana. usaha mudharabah dianggap mulai berjalan sejak dana atau modal usaha diterima oleh pengelola dana. Sedangkan pengembalian dananya dapat dilakukan secara bertahap bersamaan dengan distribusi bagi hasil atau secara total pada saat 
akad mudharabah berakhir, sesuai kesepakatan antara pemilik dana dan pegelola dana (Hery 2018, 2).

\section{Konsep Efektivitas}

Efektivitas adalah seberapa baik pekerjaan yang di lakukan, sejauh mana seseorang menghasilkan keluaran sesuai dengan yang di harapkan, dengan kata lain apabila suatu pekerjaan dapat dilakukan dengan baik sesuai dengan yang direncanakan dapat dikatakan efektif tanpa memperhatikan waktu, tenaga dan yang lainnya (Lusiana 2014).

Efektivitas adalah kemampuan untuk memilih tujuan yang tepat atau peralatan yang tepat untuk pencapaian tujuan yang telah di tetapkan, dengan kata lain seorang manager efektif dapat memilih pekerjaan yang harus dilakukan atau metode (cara) yang tepat untuk mencapai tujuan (Handoko 2003, 7). Dalam mengoptimalisasi tujuan efektivitas ini di nilai menurut ukuran seberapa jauh suatu organisasi berhasi mencapai tujuan yang layak di capai dan optimal (Sutrisno 2010, 124).

Sehubungan dengan pengertian di atas, maka efektivitas menggambarkan seluruh siklus input, proses dan output yang mengacu pada hasil guna daripada suatu organisasi, program atau kegiatan yang menyatakan sejauhmana tujuan (kualitas, kuantitas, dan waktu) telah dicapai. Oleh karena itu suatu organisasi, program dan kegiatan dikatakan efektif apabila tujuan atau sasaran yang dikehendaki dapat tercapai sesuai dengan rencana dan dapat memberikan dampak, hasil atau manfaat yang diinginkan, terdapat tiga unsur dalam efektivitas, yaitu: (1) Pencapaian tujuan, yaitu suatu kegiatan dikatakan efektif apabila dapat mencapai tujuan atau sasaran sesuai dengan yang telah ditentukan sebelumnya. (2) Ketepatan waktu, yaitu suatu kegiatan dikatakan efektif apabila penyelesaian atau pencapaian tujuan sesuai dengan waktu yang telah ditentukan. (3) Manfaat, yaitu suatu kegiatan dikatakan efektif apabila kegiatan tersebut memberikan manfaat bagi organisasi dan masyarakat sesuai dengan kebutuhannya (Erti 2016).

Dari uraian tersebut maka dapat dirumuskan hipotesis penelitian yaitu adanya pengaruh pembiayaan UED-SP terhadap efektivitas usaha masyarakat desa pada bidang pertanian Kecamatan Bantan.

\section{METODE PENELITIAN}

Populasi dalam penelitian ini adalah seluruh nasabah yang meminjam UED-SP di bidang pertanian yang ada di Kecamatan Bantan yaitu sejumlah 261 orang dari 23 Desa. Dalam penelitian digunakan adalah teknik simple random sampling. Jumlah sampel ditentukan dengan rumus solvin.

Keterangan :

$$
\mathrm{n}=\frac{\mathrm{N}}{1+\left(\mathrm{N} \times \mathrm{e}^{2}\right)}
$$

n : Jumlah Elemen / Anggota Sampel

$\mathrm{N} \quad$ : Jumlah Elemen / Anggota populasi

e : Eror level (tingkat kesalahan)

$$
\mathrm{n}=\frac{261}{1+\left(261 \times 0.05^{2}\right)}=157.94
$$


maka di ketahui sampel dalam penelitian ini sebesar 158 orang. Kemudian penentuan sporsi ampelnya memperhatikan strata (tingkatan) yang ada dalam populasi. Polulasi ini terbagi dalam 23 desa dengan jumlah tertentu dengan menggunakan Teknik Proportionate Stratified Random Sampling. Maka jumlah sampel yang di ambil berdasarkan masing-masing bagian tersebut ditentukan dengan rumus:

$$
\mathrm{n}=\frac{\text { populasi kelas }}{\text { jumlah populasi keseluruhan }} \times \text { jumlah sampel yang di tentukan }
$$

Tabel 1 Proportionate Stratified Random Sampling

\begin{tabular}{|c|c|c|c|}
\hline No & Nama Desa & Rumus & $\begin{array}{l}\text { Jumlah } \\
\text { Sampel }\end{array}$ \\
\hline 1 & Desa Pasiran & $n=\frac{3}{261} \times 158=1.81$ & 2 Orang \\
\hline 2 & Desa Bantan Air & $n=\frac{0}{261} \times 158=0$ & - \\
\hline 3 & Desa Bantan Sari & $n=\frac{1}{261} \times 158=0.60$ & 1 Orang \\
\hline 4 & Desa Bantan Tengah & $n=\frac{4}{261} \times 158=2.42$ & 2 Orang \\
\hline 5 & Desa Bantan Timur & $n=\frac{0}{261} \times 158=0$ & - \\
\hline 6 & Desa Bantan Tua & $n=\frac{6}{261} \times 158=3.63$ & 4 Orang \\
\hline 7 & Desa Berancah & $n=\frac{13}{261} \times 158=7.86$ & 8 Orang \\
\hline 8 & Desa Deluk & $n=\frac{3}{261} \times 158=1.81$ & 2 Orang \\
\hline 9 & Desa Jangkang & $n=\frac{9}{261} \times 158=5.44$ & 5 Orang \\
\hline 10 & Desa Kembung Baru & $n=\frac{1}{261} \times 158=0.60$ & 1 Orang \\
\hline 11 & Desa Kembung Luar & $n=\frac{6}{261} \times 158=3.43$ & 3 Orang \\
\hline 12 & Desa Mentayan & $n=\frac{0}{261} \times 158=0$ & - \\
\hline 13 & Desa Muntai & $n=\frac{0}{261} \times 158=0$ & - \\
\hline 14 & Desa Muntai Barat & $n=\frac{2}{261} \times 158=1.21$ & 1 Orang \\
\hline 15 & Desa Pambang Baru & $n=\frac{2}{261} \times 158=1.21$ & 1 Orang \\
\hline 16 & $\begin{array}{l}\text { Desa Pambang } \\
\text { Pesisir }\end{array}$ & $n=\frac{5}{261} \times 158=3.02$ & 3 Orang \\
\hline 17 & Desa Teluk Papal & $n=\frac{1}{261} \times 158=0.60$ & 1 Orang \\
\hline 18 & Desa Resam Lapis & $n=\frac{0}{261} \times 158=0$ & - \\
\hline 19 & Desa Selatbaru & $n=\frac{50}{261} \times 158=35.11$ & 35 Orang \\
\hline 20 & Desa Suka Maju & $n=\frac{0}{261} \times 158=0$ & - \\
\hline 21 & Desa Teluk Lancar & $n=\frac{0}{261} \times 158=0$ & - \\
\hline 22 & $\begin{array}{l}\text { Desa Teluk } \\
\text { Pambang }\end{array}$ & $n=\frac{138}{261} \times 158=83.54$ & 84 Orang \\
\hline 23 & Desa Ulupulau & $n=\frac{\pi}{261} \times 158=5.44$ & 5 Orang \\
\hline \multicolumn{3}{|c|}{ Jumlah Sampel } & 158 Orang \\
\hline
\end{tabular}

Sumber: Data olahan 
Dalam penelitian ini data yang diperoleh melalui wawancara, kuesioner, Dokumentasi dan studi kepustakaan. Adapun teknik analisis data yang digunakan dalam penelitian ini adalah uji validitas, uji reliabilitas, uji normalitas, uji hipotesis, uji regresi linier sederhana dan Uji koefisien determinasi.

\section{HASIL DAN PEMBAHASAN PENELITIAN}

\section{Pembiayaan UED-SP}

Berikut rekapitulasi pembiayaan Ued-Sp tahun 2014-2018 pada usaha pertanian Kecamatan Bantan dapat dilihat pada tabel berikut:

Tabel 2 Penyaluran Dana UED-SP Pada Usaha Usaha Pertanian Untuk 23 Desa Di Kecamatan Bantan

\begin{tabular}{ccccc}
\hline Tahun & $\begin{array}{c}\text { Jumlah } \\
\text { Anggaran }\end{array}$ & $\begin{array}{c}\text { Jumlah } \\
\text { Penyaluran }\end{array}$ & $\mathbf{( \% )}$ & Ket. \\
\hline 2014 & $\mathrm{Rp} 1.875 .000 .000$ & $\mathrm{Rp} 1.875 .000 .000$ & $100 \%$ & Tersalurkan \\
2015 & $\mathrm{Rp} 1.950 .000 .000$ & $\mathrm{Rp} 1.950 .000 .000$ & $100 \%$ & Tersalurkan \\
2016 & $\mathrm{Rp} 1.980 .000 .000$ & $\mathrm{Rp} 1.980 .000 .000$ & $100 \%$ & Tersalurkan \\
2017 & $\mathrm{Rp} 1.820 .000 .000$ & $\mathrm{Rp} 1.820 .000 .000$ & $100 \%$ & Tersalurkan \\
2018 & $\mathrm{Rp} 2.133 .000 .000$ & $\mathrm{Rp} 2.133 .000 .000$ & $100 \%$ & Tersalurkan \\
\hline
\end{tabular}

Sumber: (Kabupaten Bengkalis 2019)

\section{Data Responden}

Berdasarkan kuesioner yang disebarkan kepada responden, maka diperoleh data yang berkenaan dengan responden yang menjadi sampel dalam penelitian mencakup hal-hal mengenai jenis kelamin dan umur yang menjadi responden dalam penelitian ini. Kuesioner yang disebar sebanyak 158 buah kuesioner, yang kembali sebanyak 158 buah. setelah dilakukan Karakteristik responden dalam penelitian ini terbagi dalam beberapa kategori, yaitu: gender (jenis kelamin), dan umur.

\begin{tabular}{cccc}
\multicolumn{4}{c}{ Tabel 3 Distribusi Responden Berdasarkan Jenis Kelamin } \\
\hline No & Jenis Kelamin & Jumlah (Orang) & Persentase (\%) \\
\hline 1 & Laki-laki & 124 & 78.48 \\
2 & Perempuan & 34 & 21.52 \\
\hline & Jumlah & $\mathbf{1 5 8}$ & $\mathbf{1 0 0}$ \\
\hline
\end{tabular}

Sumber: Data olahan

Tabel 4 Distribusi Responden Berdasarkan Usia

\begin{tabular}{clccc}
\hline No & \multicolumn{1}{c}{ Usia } & Interval & $\begin{array}{c}\text { Jumlah } \\
\text { (Orang) }\end{array}$ & $\begin{array}{c}\text { Persentase } \\
(\%)\end{array}$ \\
\hline 1 & Anak-anak & $5-11$ & 0 & 0 \\
2 & Remaja & $12-25$ & 32 & 20.25 \\
3 & Dewasa & $26-44$ & 89 & $56.33 \%$ \\
4 & Lansia & $45-65$ & 37 & $23.42 \%$ \\
\hline \multicolumn{2}{r}{ Jumlah } & & $\mathbf{1 5 8}$ & $\mathbf{1 0 0 \%}$ \\
\hline
\end{tabular}

Sumber: Data olahan 
Tabel 5 Descriptive Statistic

\begin{tabular}{lccccc}
\hline & N & Minimum & Maximum & Mean & Std. Deviation \\
\hline Pembiayaan UED-SP & 158 & 8 & 42 & 16.81 & 4.416 \\
Efektifitas Usaha & 158 & 9 & 24 & 15.85 & 2.902 \\
Masyarakat Desa & & & & & \\
Valid N (listwise) & 158 & & & & \\
Sumber: Output SPSS & & & &
\end{tabular}

Berdasarkan tabel $5 \mathrm{di}$ atas, dapat dilihat pada pembiayaan UED-SP bahwa nilai rata-rata sebesar 16,81 dengan standar deviasi sebesar 4,416, ini menunjukkan bahwa terdapat penyebaran data yang baik karena nilai rata-rata lebih besar daripada standar deviasi pembiayaan UED-SP. Kemudian dapat dilihat pada efektifitas usaha masyarakat desa bahwa nilai rata-rata sebesar 15,85 dengan standar deviasi sebesar 2,902, ini menunjukkan bahwa terdapat penyebaran data yang baik karena nilai rata-rata lebih besar daripada standar deviasi efektifitas usaha masyarakat desa.

\section{Uji Validitas}

Uji validitas digunakan untuk mengetahui kevalidan kuesioner dalam mengumpulkan data. Perhitungan validitas angket pada pengaruh pembiayaan Ued-Sp terhadap efektivitas usaha masyarakat desa pada bidang pertanian terdiri dari 18 buah pernyataan. uji validitas di lakukan dengan alat bantu program SPSS versi 17.0. Item Kuesioner dalam uji validitas dikatakan valid jika $R_{\text {tabel }}<R_{\text {hitung }}$ pada tingkat signifikan 5\%. dan sebaliknya item angket dikatakan tidak valid jika

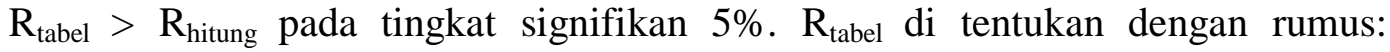
$d f=N-2 . d f=158-2=156$. Sehingga di ketahui $\mathrm{R}_{\text {tabel }}=0.1562$.

\section{Tabel 6 Hasil Uji Validitas Variabel X}

\begin{tabular}{cccc} 
No. & $\mathbf{R}_{\text {hitung }}$ & $\mathbf{R}_{\text {tabel }}$ & Keterangan \\
\hline 1 & 0,658 & 0,1562 & Valid \\
2 & 0,590 & 0,1562 & Valid \\
3 & 0,612 & 0,1562 & Valid \\
4 & 0,514 & 0,1562 & Valid \\
5 & 0,485 & 0,1562 & Valid \\
6 & 0,568 & 0,1562 & Valid \\
7 & 0,592 & 0,1562 & Valid \\
8 & 0,514 & 0,1562 & Valid \\
\hline
\end{tabular}

Sumber: Data olahan

Tabel 7 Hasil Uji Validitas Variabel Y

\begin{tabular}{cccc}
\hline No. & $\mathbf{R}_{\text {hitung }}$ & $\mathbf{R}_{\text {tabel }}$ & Keterangan \\
\hline 1 & 0,670 & 0,1562 & Valid \\
2 & 0,607 & 0,1562 & Valid \\
3 & 0,246 & 0,1562 & Valid \\
4 & 0,194 & 0,1562 & Valid \\
5 & 0,547 & 0,1562 & Valid
\end{tabular}




\begin{tabular}{cccc}
6 & 0,530 & 0,1562 & Valid \\
7 & 0,338 & 0,1562 & Valid \\
8 & 0,333 & 0,1562 & Valid \\
\hline \multicolumn{3}{l}{ Sumber: Data olahan }
\end{tabular}

\section{Uji Reliabilitas}

Setelah instrumen penelitian diuji validitasnya, maka dilanjutkan dengan uji reliabilitas instrumen untuk mengetahui tingkat kepercayaan instrumen penelitian yang digunakan sebagai alat pengumpulan data. Uji reliabilitas terhadap instrumen penelitian yang dihitung menggunakan rumus cronbach's alpha. Suatu instrumen penelitian dikatakan reliabel apabila nilai instrumen reliabilitas itu sendiri memiliki nilai reliabilitas $\geq 0,60$. Tetapi jika nilai reliabilitas instrumen $\leq$ 0,60 maka instrumen tidak reliabel dan tak dapat digunakan dalam penelitian.

\section{Tabel 8 Hasil Uji Reliabilitas}

\begin{tabular}{cc} 
Cronbach's Alpha & N of Items \\
\hline, 802 & 16 \\
\hline Sumber: Output SPSS &
\end{tabular}

Berdasarkan tabel 8 di atas, menunjukkan hasil pengujian reliabilitas dengan nilai cronbash's Alpha adalah $0,802>0,60$ sehingga dapat dikatakanbahwa seluruh instrumen yang digunakan tersebut reliabel untuk digunakan.

\section{Uji Normalitas}

Uji normalitas pada model regresi digunakan untuk menguji apakah nilai residual yang dihasilkan dari regresi terdistribusi secara normal atau tidak. Uji normalitas data dalam penelitian ini menggunakan Uji One Sample KolmogorovSmirnov (Uji K-S). Dasar pengambilan keputusan pada uji normalitas ini adalah: jika signifikan/probabilitas > 0,05 maka data berdistribusi normal, jika nilai signifikan/probabilitas $<0,05$ maka data berdistribusi tidak normal.

Tabel 9 Uji Normalitas Pembiayaan Ued-Sp

\begin{tabular}{llc}
\hline & & Pembiayaan UED-SP \\
\hline$N$ & & 158 \\
Normal & Mean & 16,81 \\
Parameters $^{a, b}$ & Std. Deviation & 4,416 \\
Most Extreme & Absolute &, 084 \\
Differences & Positive &, 084 \\
& Negative &,- 080 \\
Kolmogorov-Smirnov Z & 1,052 \\
Asymp. Sig. (2-tailed) &, 219 \\
\hline a. Test distribution is Normal. & \\
b. Calculated from data. & \\
Sumber: Output SPSS &
\end{tabular}


Hasil uji normalitas untuk variabel Pembiayaan UED-SP pada tabel 9 di atas dapat dilihat 158 responden yang digunakan sebagai sampel penelitian Nilai KS hitung= 1.052 nilai Asym Sig. sebesar 0.219. Nilai Asym Sig selanjutnya dibandingkan dengan nilai Signifikan sebesar 0,05 atau 5\%. maka nilai Asym Sig lebih besar dari nilai Sig yaitu $(0.219>0,05)$, maka distribusi data untuk variabel Pembiayaan UED-SP tersebut normal.

\begin{tabular}{llc}
\multicolumn{2}{l}{ Tabel 10 Uji Normalitas Efektivitas Usaha Masyarakat Desa } & $\begin{array}{r}\text { Efektifitas Usaha } \\
\text { Masyarakat Desa }\end{array}$ \\
\hline$N$ & 158 \\
Normal & Mean & 15,85 \\
Parameters, & Std. Deviation & 2,902 \\
Most Extreme & Absolute &, 099 \\
Differences & Positive &, 099 \\
& Negative &,- 075 \\
Kolmogorov-Smirnov Z & 1,249 \\
Asymp. Sig. (2-tailed) &, 088 \\
\hline a. Test distribution is Normal. & \\
b. Calculated from data. & \\
Sumber: Output SPSS &
\end{tabular}

Hasil uji normalitas untuk variabel efektivitas usaha masyarakat desa pada bidang pertanian pada tabel diatas dapat dilihat 158 responden yang digunakan sebagai sampel penelitian Nilai KS hitung=1.249 nilai Asym Sig. sebesar 0.088. nilai Asym Sig selanjutnya dibandingkan dengan nilai Signifikan sebesar 0,05 atau 5\%. maka nilai Asym Sig lebih besar dari nilai Sig yaitu $(0,088>0,05)$, maka distribusi data untuk variabel efektivitas usaha masyarakat desa pada bidang pertanian tersebut normal.

Uji Regresi Linier Sederhana

Tabel 11 Coefficients ${ }^{\mathrm{a}}$

\begin{tabular}{|c|c|c|c|c|c|}
\hline \multirow[t]{2}{*}{ Model } & \multicolumn{2}{|c|}{$\begin{array}{l}\text { Unstandardized } \\
\text { Coefficients }\end{array}$} & \multirow{2}{*}{$\begin{array}{c}\text { Standardized } \\
\text { Coefficients } \\
\text { Beta }\end{array}$} & \multirow[t]{2}{*}{$t$} & \multirow[t]{2}{*}{ Sig. } \\
\hline & $B$ & Std. Error & & & \\
\hline 1 (Constant) & 7,677 &, 615 & & 12,478 & , 000 \\
\hline $\begin{array}{l}\text { Pembiayaan } \\
\text { UED-SP }\end{array}$ & ,486 & ,035 & ,740 & 13,728 & , 000 \\
\hline
\end{tabular}

Dari tabel 11 di atas, diketahui nilai constant (a) sebesar 7,677, sedangkan nilai pembiayaan UED-SP (b/koefisien regresi) sebesar 0,486 sehingga persamaan regresinya dapat di tulis: $Y=a+b X+e, \quad Y=7.677+0.486 X+e$. Nilai constant (a) sebesar 7.677. Mengandung arti bahwa nilai kosisten variabel 
efektivitas usaha masyarakat desa pada bidang pertanian (Y) sebesar 7.677. Sedangkan koefesien regresi variabel penyaluran pembiayaan dana UED-SP (X) sebesar 0.486 menyatakan bahwa setiap penambahan $1 \%$ nilai pembiayaan UedSp, maka nilai pembiayaan Ued-Sp bertambah sebesar 0.486. dapat diketahui nilai koefisien regresi tersebut bernilai positif. sehingga dapat dikatakan bahwa ada arah pengaruh variabel pembiayaan UED-SP (X) terhadap efektivitas usaha masyarakat desa pada bidang pertanian (Y) adalah positif.

\section{Uji t}

Uji $t$ digunakan untuk mengetahui apakah variabel independen berpengaruh secara signifikan atau tidak terhadap variabel dependen (Sugiyono 2014, 261). Untuk melihat pengaruh variabel dependen terhadap variabel independen, uji $\mathrm{t}$ dilakukan dengan membandingkan nilai $t_{\text {hitung }}$ dengan $t_{\text {tabel }}$ dengan kriterianya yaitu: jika $t_{\text {hitung }}<\mathrm{t}_{\text {tabel }}$ maka hipotesis ditolak berarti tidak ada pengaruh, jika $t_{\text {hitung }}>t_{\text {tabel }}$ maka hipotesis diterima berart terdapat pengaruh.

Diketahui nilai $t_{\text {tabel }}$ pada taraf signifikasi 5\% (2-tailed) dengan persamaan berikut: $\mathrm{df}=\mathrm{n}-2 ; \quad$ alpha $=5 \%, \mathrm{df}=158-2 ; 0.05 / 2, \mathrm{df}=156 ; 0,025, \mathrm{~T}_{\text {tabel }}=1,975$. Berdasarkan output tabel 11 di atas, diketahui nilai $t_{\text {hitung }}(13,728)>t_{\text {tabel }}(1,975)$ artinya hipotesis diterima.

\section{Koefisien Determinasi $\left(\mathbf{R}^{2}\right)$}

Uji koefisien determinasi $\left(\mathrm{R}^{2}\right)$ digunakan untuk mengetahui persentase pengaruh variabel independen $(\mathrm{X})$ terhadap variabel dependen $(\mathrm{Y})$. Persentase tersebut menunjukkan seberapa besar variabel independen dapat menjelaskan variabel dependen. Semakin besar koefisien determinasinya, maka semakin baik variabel independen dalam menjelaskan variabel dependennya.

Tabel 12 Model Summary

\begin{tabular}{|c|c|c|c|c|}
\hline Model & $\boldsymbol{R}$ & R Square & Adjusted R Square & $\begin{array}{c}\text { Std. Error of the } \\
\text { Estimate }\end{array}$ \\
\hline 1 &, $740^{\mathrm{a}}$ & ,547 & ,544 & 1,959 \\
\hline
\end{tabular}

Dapat dilihat pada tabel 12 dimana $\mathrm{R}=0,740$, berarti hubungan pembiayaan UED-SP dengan efektivitas usaha masyarakat desa adalah kuat, Sedangkan besar pengaruh pembiayaan UED-SP terhadap efektifitas usaha masyarakat desa pada bidang pertanian Kecamatan Bantan adalah sebesar 54,4\%, sedangkan sisanya $45,6 \%$ merupakan faktor lainnya diluar model regresi penelitian ini.

Untuk melihat pengaruh pembiayaan UED-SP terhadap efektivitas usaha masyarakat desa pada bidang pertanian Kecamatan Bantan digunakan uji t. Dari uji t didapat bahwa hipotesis diterima yang artinya terdapat pengaruh yang signifikan antara pembiayaan UED-SP terhadap efektivitas usaha masyarakat desa pada bidang pertanian Kecamatan Bantan. Pengaruh pembiayaan UED-SP terhadap efektivitas usaha masyarakat desa pada bidang pertanian Kecamatan Bantan sebesar 54,4\%. Secara keseluruhan pembiayaan pada UED-SP telah diterapkan di seluruh Desa di Kecamatan Bantan dengan tujuan untuk 
pemberdayaan masyarakat serta meningkatkan prekonomian masyarakat. Hasil penelitian ini sama dengan penelitian terdahulu yang dilakukan oleh Astuti (2017) menyebutkan bahwa terdapat pengaruh yang sangat signifikansi antara adalah Pembiayaan UED-SP terhadap usaha petani padi.

\section{KESIMPULAN}

Dari hasil penelitian dapat disimpulkan bahwa terdapat pengaruh antara pembiayaan UED-SP terhadap efektivitas usaha masyarakat desa pada bidang pertanian Kecamatan Bantan. Dimana besar pengaruh pembiayaan Ued-Sp terhadap efektivitas usaha masyarakat desa pada bidang pertanian Kecamatan Bantan adalah 54,4\%, sedangkan sisanya $45,6 \%$ merupakan faktor lainnya.

Berdasarkan hasil penelitian yang telah dilakukan dalam rangka mengetahui pengaruh pembiayaan UED-SP terhadap efektivitas usaha masyarakat desa pada bidang pertanian Kecamatan Bantan, maka saran peneliti adalah UEDSP yang ada di Kecamatan Bantan dapat meningkatkan pembiayaan UED-SP terhadap masyarakat agar dapat meningkatkan prekonomian desa kemudian UEDSP harus menerapkan sanksi keterlambatan yang jelas bagi masyarakat yang meminjam.

\section{DAFTAR PUSTAKA}

Alma, Buchari dan Donni Juni Priansa. 2014. Manajemen Bisnis Syariah. Bandung: Alfabeta.

Andoko, T. Hani. 2003. Manajemen. Yogyakarta: BPFE Yogyakarta.

Anggadini, Sri Dewi dan Adeh Ratna Kemala. 2017. Akuntansi Syariah. Bandung: Rekayasa Sains.

Antonio, Muhammad Syafi'i. 2001. Bank Syariah (Dari Teori Ke Praktik). Jakarta: Gema Insani.

Aryani, Titin. 2018. "Pengaruh Kinerja Unit Usaha Simpan Pinjam (UED-SP)

Terhadap Kesejahteraan Debitur Desa Nipah Sendanu Kecamatan Tebing Tinggi Timur". Skripsi Sekolah Tinggi Ilmu Ekonomi (STIE) Syariah Bengkalis.

Astuti, Dian. 2017. “Analisis Pembiayaan Usaha Ekonomi Simpan Pinjam Dalam Pemberdayaan Petani Pada Kampung Laksamana Kec. Sabak Auh Kab. Siak”. Skripsi Sekolah Tinggi Ilmu Ekonomi (STIE) Syariah Bengkalis. 2017.

Bungin, Burhan. 2005. Metodologi Penelitian Sosial Dan Ekonomi. Jakarta: Kencana.

Bungin, Burhan. 2011. Metodologi Penelitian Kuantitatif: Komunikasi, Ekonomi, dan Kebijakan Publik serta Ilmu-ilmu Sosial Lainnya. Jakarta: Kencana.

Erti, Jasma. 2016. "Efektivitas Program Usaha Ekonomi Desa Simpan Pinjam (UED-SP) Dalam Meningkatkan Kesejahteraan Ekonomi Masyarakat Desa Sawah Kecamatan Kampar Utara”. Jom FISIP Universitas Riau, $3(1)$.

Hery. 2018. Akuntansi Syariah. Jakarta: Kompas Gramedia.

Hermansyah. 2006. Hukum Perbankkan Nasional Indonesia. Jakarta: Kencana. 
Ilyas, Rahmad. 2015. "Konsep Pembiayaan Dalam Bank Syariah”. Jurnal Penelitian 9 (1).

Kabupaten Bengkalis. 2019. Hasil Dokumentasi dari Dinas Pemberdayaan Masyarakat Dan Desa (DPMD) Kabupaten Bengkalis. 25 Januari 2019.

Karim, Adiwarman A. 2006. Bank Islam (Analisis Fiqih Dan Keuangan). Jakarta: Raja Grafindo Persada.

Kementrian Dalam Negeri. 1998. Peraturan Menteri Dalam Negeri Nomor 6 Tahun 1998 Pasal 3 tentang Usaha Ekonomi Desa Simpan Pinjam (UED$S P)$.

Lusiana. 2014. "Efektivitas Penyaluran Dana Usaha Ekonomi Desa-Simpan Pinjam (UED-SP) Kepada Masyarakat Di Desa Sungai Salak, Kecamatan Rambah Samo Kabupatem Rokan Hulu". Jom FISIP Universitas Riau 1 (2).

Mahkota. 2002. Al-Qur'an Dan Terjemahan. Terjemahan Yayasan Penyelenggara Penterjemah Al-Qur'an. Jakarta: Mahkota Surabaya.

Mardani. 2012. Fiqh Ekonomi Syariah. Jakarta: Kencana.

Muhammad. 2011. Manajemen Bank Syariah. Yogyakarta: UPP STIM YKPN.

Muhammad, Rifqi. 2008. Akuntansi Keuangan Syariah (Konsep dan Implementasi PSAK Syariah). Yogyakarta: P3EI Press.

Muri, Yusuf. 2014. Metodologi Penelitian Kuantitatif, Kualitatif Dan Penelitian Gabungan. Jakarta: Prenadamedia Group.

Noor, Juliansyah. 2012. Metodologi Penelitian. (Skripsi, Tesis, Disertasi, Karya Ilmiah). Jakarta: Kencana.

Rahman. 2005. Kamus Besar Bahasa Indonesia. Jakarta: Trimedia.

Saputra, Hendri. 2014. "Efektifitas Pembiayaan Mikro Terhadap Usaha Nasabah Pada PT.Bank Syariah Mandiri KCP.Bengkalis". Skripsi Sekolah Tinggi Ilmu Ekonomi (STIE) Syariah Bengkalis.

Siamat, Dahlan. 2001. Manajemen Lembaga Keuangan. Jakarta: Lembaga Penerbit Fakultas Ekonomi Univesitas Indonesia.

Siregar, Baldric. 2015. Akuntansi Sektor Publik (Akuntansi Keuangan Pemerintah Daerah Berbasis Akrual). Yogyakarta: UPP STIM YKPN.

Siregar, Syofian. 2010. Statistika Deskriptif untuk Penelitian: Dilengkapi Perhitungan Manual dan Aplikasi SPSS Versi 17. Jakarta: PT Raja Grafindo Persada.

Siregar, Syofian. 2013. Metode Penelitian Kuantitatif: Dilengkapi Perhitungan Manual dan SPSS. Jakarta: Kencana.

Sjahdein, Sutan Remy. 2014. Perbankan Syariah (Produk-Produk Dan AspekAspek Hukumnya). Jakarta: Kencana.

Soemitra, Andri. 2009. Bank \& Lembaga Keuangan Syariah. Jakarta: Kencana.

Sugiyono. 2004. Metodologi Penelitian Bisnis. Bandung: Alfabeta.

Sugiyono. 2014. Statistik Untuk Penelitian. Bandung: Alfabeta.

Sugiyono. 2017. Metode Penelitian Kuantitatif, Kualitatif Dan R\&D. Bandung: Alfabeta.

Sutrisno, Edi. 2010. Budaya Organisasi. Jakarta: Kencana.

Usanti, Trisadini P. dan Abd. Somad. 2013. Transaksi Bank Syariah. Jakarta: Bumi Aksara. 